\title{
Actions in inclusive education from Latin America for the world
}

\author{
Acciones en educación inclusiva de América Latina para el mundo
}

\author{
Karina Delgado Valdivieso \\ Centro de Investigación de Ciencias Humanas y de la Educación \\ Universidad Tecnológica Indoamérica, Quito, Ecuador \\ karinadelgado@uti.edu.ec
}

Fecha recepción: 11-04-2020

Páginas 109-118

Fecha aceptación: 20-05-2020

\begin{abstract}
.
The Countries in Latin America, in respect to education, have the responsibility to assume national and international law, given through declarations, letters, conventions and regulations that describe it as a service for all. Inclusive education performs a service that is equal for everyone, as well as it evidences new work challenges based on the learning needs of each student. Method. Qualitative research was carried out, which described the criteria adopted in the area of inclusive education in the different countries of the region. Quantitative research, which derived variables according to the different conditions presented by the students such as: social, intercultural and personal. Results The analyzes are described in i) reasons given to make an inclusive education; and ii) understand inclusive education according to new work challenges and the learning needs of each student, considering their social, intercultural and personal conditions. Discussion. These results show the need to propose, according to the context of Latin America, a Model of Actions in Inclusive Education, described in three dimensions: educational policy, conditions that the students present, and different actions derived from those conditions.
\end{abstract}

Keywords: inclusive education, diversity, social, intercultural and personal conditions

\section{Resumen.}

Los Estados en América Latina, con respecto a la educación, tienen la responsabilidad de asumir el derecho internacional y nacional, dado a través de declaraciones, cartas, convenciones y normativas que describen un servicio para todos. La educación inclusiva realiza un servicio que equitativamente es para todos, así como evidencia nuevos retos de trabajo en función de las necesidades de aprendizaje de cada uno de los estudiantes. Método. Se realizó una investigación cualitativa, que describió los criterios adoptados en materia de educación inclusiva en los diferentes países de la región, y una investigación cuantitativa, que deriva variables en función de brechas según las diferentes condiciones que presenten los estudiantes como: sociales, interculturales y personales. Resultados. Los análisis se 
describen en i) razones dadas para hacer una educación inclusiva; y ii) comprender la educación inclusiva según nuevos retos de trabajo en función de las necesidades de aprendizaje de cada uno de los estudiantes, considerando sus condiciones sociales, interculturales y personales. Discusión. Estos resultados evidencian la necesidad de plantear según el contexto de América Latina un Modelo de Acciones en Educación Inclusiva, descrito en tres dimensiones: políticas educativas, condiciones que presenten los estudiantes, y diferentes acciones derivadas de las condiciones.

Palabras clave: educación inclusiva, diversidad, condiciones sociales, interculturales y personales

\section{Introduction.}

«I don't feel like going to school», Andrés.

«There is no better school than a book», Nicolás.

«How does learning Math help me? », Paula.

«My son does not learn the same as others» Cristina.

«How are the things that I am learning useful for me?», Juan.

«How do we tend all of the student's needs?», Carmen.

«Because they do not value Geovanny's skills», Belén

«My crimes, raise my voice for education and peace», Malala.

«How do I work with a student who has dyscalculia», Karina.

«My goal is to be an athlete, but I also want to study», Matías.

"She has already reached the baccalaureate, but she will not be able to go to university", Delia.

«How to reduce learning gaps between students who come from economically more advantaged sectors and students who belong to economically disadvantaged and / or vulnerable groups», UNESCO.

These are the opinions of students, teachers, parents, directors of institutions and organizations that have not yet found answers to achieve adequate learning within the Educational System.

The countries of Latin America through their States, as an intention, have the responsibility by law to define instruments that seek social equality. In the last decades: declarations, letters and conventions have been developed to regulate obligations that comply with legislative measures. In addition, it shows the laws that describe a service for all, through the approach and adaptation of legislative measures to achieve an equitable education.

The countries of Latin America, through their Educational Systems will assume the responsibility of achieving the learning of all the students, in which they seek to do a job based on their particularities, that is to say moving from a focus on homogeneity to heterogeneity of the students. Educational heterogeneity is developed from an inclusive education. 
Inclusive education is a service to all students that guarantees their attendance, participation and academic success (UNESCO, 2001). Inclusion provides a service of equality for all the inhabitants of a society. An equitable society implies the approach and application of the law, described internationally and locally for all sectors that demand it (Meléndez, 2012). Inclusive education, as an action, develops its understanding from a new approach that shows an attention to the diversity of students.

Within the framework of what has been described above, the actions given in terms of inclusive education in the countries of Latin America are shown as a reference for the world, given in treaties, conventions, and movements in countries of the region and worldwide. In addition, statistical data is included which describes the gaps related to the lack of actions to achieve an inclusive education that is at the service of all. Finally, processes for an inclusive education are developed for the Latin American context using actions for an inclusive education.

\section{Objective of the study.}

The purpose of this study is to describe the actions carried out in the area of inclusive education within the Latin American countries in search of becoming a benchmark for the rest of the world. The objectives pursued with this study are: i) to characterize the normative framework in the field of inclusive education, as a reference for the world, and ii) to describe the reasons why an inclusive education work is demanded in the countries of Latin America.

\section{Method.}

\section{Design of the investigation.}

The methodology used for this study is based on i) qualitative research; (Taylor and Bogdan, 1996) described it as "one that produces descriptive data: people's own words, spoken or written, and observable behavior" (p.20). For the purpose of this research, the adopted criteria is determined considering the social reality implemented in the different countries of the region, and ii) quantitative research; associated with a mathematically accurate analysis avoiding subjectivity to make effective assertions, (Argimon, and Jiménez, 2004). This study worked with variables that analogically constitute the gaps given in terms of the different conditions that may affect the students.

\section{Results.}

\section{Reasons for inclusive education.}

UNESCO's Movement Education for All. 
Movements have allowed the creation spaces to analyze attention according to needs presented by different groups. The World Conference on Education for All of Jomtien in 1990 made its analysis based on problems such as limited education. Basic education was focused on literacy and how marginal groups faced the risk of being totally excluded. The problems found were evaluated for their compliance in the International Consultative Forum on Education for All of Amman in 1996. The World Forum of Education for All at Dakar in $\mathbf{2 0 0 0}$ made an analysis regarding the exclusion processes that continues to be experienced by less privileged groups, including children, young people and working adults who live in rural areas, who are affected by: conflicts, HIV / AIDS, hunger, poor health and those with special needs for accessibility and learning.

\section{Movements according to particularities of different groups.}

The rights to an inclusive education have been reinforced according to the particularities of different groups. The Convention on the Elimination of All Forms of Discrimination against Women in 1981, the International Convention on the Protection of the Rights of All Migrant Workers and Members of Their Families in 1990, the Declaration of Salamanca in 1994 developed through the World Conference on Special Educational Needs in 1994, the Inter-American Convention on the Elimination of All Forms of Discrimination against People with Disabilities in 2001, the Convention on the Rights of People with Disabilities in 2006, the Universal Declaration on Cultural Diversity in 2002; and the United Nations Declaration on the Rights of Indigenous People in 2006.

\section{Regulations in the framework of inclusive education}

Table 1 shows a description of the regulations that support a work in inclusive education in the Latin American region.

Table1.-Systematization of inclusive education policies.

\begin{tabular}{|c|c|c|}
\hline Country & Law/coverage & Contextualization of Inclusive Education \\
\hline Argentina & $\begin{array}{l}\text { Law of National } \\
\text { Education } \mathrm{N}^{\circ} 26.206 \\
(2006)\end{array}$ & $\begin{array}{l}\text { Educational equality, to ensure the necessary conditions for } \\
\text { inclusion. It seeks the recognition, integration and educational } \\
\text { achievement of all children, young people and adults at all } \\
\text { levels and modalities, prioritizing the levels of compulsory } \\
\text { education. }\end{array}$ \\
\hline Bolivia & $\begin{array}{l}\text { Law of Education } \\
\text { "Avelino Siñani - } \\
\text { Elizardo Pérez" } \\
\text { (2010) }\end{array}$ & $\begin{array}{l}\text { Service to the diversity of population groups and people, } \\
\text { offers an opportune and pertinent education to the needs, } \\
\text { expectations and interests of all the inhabitants of the } \\
\text { Plurinational State, with equal opportunities and conditions } \\
\text { and without any discrimination. }\end{array}$ \\
\hline Brasil & $\begin{array}{l}\text { Law of Education } \\
9.304 \text { (1996). }\end{array}$ & $\begin{array}{l}\text { Public school education, given by guaranteeing a } \\
\text { fundamental, mandatory and free education, even for those } \\
\text { who did not have access to it at the propper age. It } \\
\text { guarantees the obligatory nature and free of charge of }\end{array}$ \\
\hline
\end{tabular}




\begin{tabular}{|c|c|c|}
\hline & & $\begin{array}{l}\text { secondary education, it describes the development of } \\
\text { integrated teaching and research programs for the supply of } \\
\text { bilingual and intercultural school education to indigenous } \\
\text { people. }\end{array}$ \\
\hline Chile & $\begin{array}{l}\text { School Inclusion Law, } \\
\text { (2015) and General } \\
\text { Education Law (2017). }\end{array}$ & $\begin{array}{l}\text { Actions of the system will tend to eliminate all forms of } \\
\text { arbitrary discrimination that impede the learning and } \\
\text { participation of the students, it will favor that educational } \\
\text { establishments become a meeting place among students of } \\
\text { different socioeconomic status, culture, ethnic group, gender, } \\
\text { nationality or religion. }\end{array}$ \\
\hline Colombia & $\begin{array}{lrr}\text { General } & \text { Law } & \text { of } \\
\text { Education } & \mathrm{N}^{\circ} & 115 \\
\text { (1994). } & & \end{array}$ & $\begin{array}{l}\text { Equal educational service, categorizes people with limitations, } \\
\text { as well as education according to the context for ethnic, } \\
\text { peasant and rural groups, and for people deprived of liberty. }\end{array}$ \\
\hline
\end{tabular}

\begin{tabular}{lll}
\hline Costa Rica & $\begin{array}{l}\text { Fundamental Law of } \\
\text { Education } \mathrm{N}^{\circ} 2160 \\
\text { (2001). }\end{array}$ & $\begin{array}{l}\text { It cites special needs education, being a set of support and } \\
\text { services available to students with special educational needs, } \\
\text { whether they require them temporarily or permanently. }\end{array}$ \\
\hline Cuba & $\begin{array}{l}\text { Law of General } \\
\text { Nationalization and } \\
\text { Gratuity of Education } \\
\text { (1961). }\end{array}$ & $\begin{array}{l}\text { It cites a teaching to be given free of charge to guarantee the } \\
\text { right of all citizens to receive it without distinctions or } \\
\text { privileges. }\end{array}$ \\
\hline Ecuador & $\begin{array}{l}\text { Organic Law of } \\
\text { Intercultural and } \\
\text { Bilingual Education } \\
\text { (201). }\end{array}$ & $\begin{array}{l}\text { The State guarantees universal access, promotes special } \\
\text { policies and programs, and provides the necessary resources } \\
\text { to facilitate the regular schooling of girls, boys and } \\
\text { adolescents who, due to social inequity, present difficulties of } \\
\text { educational insertion, significant school mismatch, or, that for } \\
\text { any reason they demand compensatory interventions } \\
\text { because of their late incorporation to education. }\end{array}$
\end{tabular}

\begin{tabular}{lll}
\hline El Salvador & $\begin{array}{l}\text { Law of General } \\
\text { Education (2005). }\end{array}$ & $\begin{array}{l}\text { It cites special education as a teaching-learning process that } \\
\text { is offered, through specific and administered methodologies, } \\
\text { to people with special educational needs. It will be exercised } \\
\text { in specialized institutions and regular educational centers, } \\
\text { according to the needs of the student, with the attention of a } \\
\text { specialist or trained teachers. }\end{array}$ \\
\hline Guatemala & $\begin{array}{l}\text { National Education } \\
\text { Law. } \\
\text { (1991). }\end{array}$ & $\begin{array}{l}\text { It cites special education, as an educational process through } \\
\text { programs for people who have deficiencies in the } \\
\text { development of language, intellectual capacities, physical and } \\
\text { the sensory and / or give evidence of higher than normal } \\
\text { capacity. Also, it cites in other chapters coeducation, bilingual } \\
\text { education and education for the mature (people who did not } \\
\text { attend the middle level). }\end{array}$ \\
\hline Haití & $\begin{array}{l}\text { Constitutión (1987). } \\
\text { Basic and High School and access to free education for all; this responsibility is } \\
\text { Levels. }\end{array}$ & $\begin{array}{l}\text { Rigsumed by the State, in the case of children. The State is } \\
\text { abligated to favor the assistance of all without distinction } \\
\text { under any excuse. }\end{array}$ \\
\hline Honduras & $\begin{array}{l}\text { Fundamental Law of } \\
\text { Education. } \\
\text { (2012). }\end{array}$ & $\begin{array}{l}\text { Educational service in equal conditions without any } \\
\text { discrimination, it meets the educational needs as central } \\
\text { elements in the development of students, recognizes, } \\
\text { respects and stimulates the different pecularities and cultural } \\
\text { identities. }\end{array}$ \\
\hline
\end{tabular}


Revista Internacional de Apoyo a la Inclusión, Logopedia, Sociedad y Multiculturalidad.

Volumen 6, Número 2, Junio 2020, ISSN: 2387-0907. DOI: https://doi.org/10.17561/riai.v6.n2.12

\begin{tabular}{|c|c|c|}
\hline México & $\begin{array}{l}\text { General Law } \\
\text { Education (1993). }\end{array}$ & $\begin{array}{l}\text { Educational equity as the decision of the authorities to } \\
\text { establish conditions for the full exercise of the right to quality } \\
\text { education of each individual, greater educational equity, as } \\
\text { well as the achievement of effective equality in access } \\
\text { opportunities, transit and permanence in educational services }\end{array}$ \\
\hline Nicargua & $\begin{array}{lcr}\text { General } & \text { Law } & \text { of } \\
\text { Education } & N^{\circ} \quad 582 \\
\text { (2006). } & & \end{array}$ & $\begin{array}{l}\text { Processes through which the schools or alternative } \\
\text { educational services incorporate: people with disabilities, } \\
\text { socially excluded, marginalized and vulnerable groups; } \\
\text { especially in rural areas, without distinction of ethnicity, } \\
\text { religion, sex or other cause of discrimination, thus contributing } \\
\text { to the elimination of poverty, exclusion and inequalities. It is } \\
\text { proposed to respond to all students as individuals by } \\
\text { reconsidering their organization and curricular proposal. }\end{array}$ \\
\hline Panamá & $\begin{array}{l}\text { Organic Law } \begin{array}{r}\text { of } \\
\text { Education } \\
\text { (1946). Law } 34 .\end{array} \\
\text { (1995). }\end{array}$ & $\begin{array}{l}\text { Education as a right and duty, will be made without distinction } \\
\text { of age, ethnicity, sex, religion, economic position, social or } \\
\text { political ideas. In an isolated way it defines the educational } \\
\text { service for people with Special Educational Needs developed } \\
\text { with the support and supervision of special teachers. }\end{array}$ \\
\hline Paraguay & $\begin{array}{llr}\text { General } & \text { Law } & \text { of } \\
\text { Education } & N^{\circ} 1264 \\
\text { (1998). } & & \end{array}$ & $\begin{array}{l}\text { Education as a compensation of inequalities, with the } \\
\text { implementation of special educational programs for groups } \\
\text { and regions that face economic, demographic and social } \\
\text { conditions. }\end{array}$ \\
\hline Perú & $\begin{array}{ll}\text { General } & \text { Law } r \\
\text { Education } & N^{\circ} 28044 \\
\text { (2003). } & \end{array}$ & $\begin{array}{l}\text { Comprehensive and democratic quality education, that will be: } \\
\text { supportive and inclusive, it will compensate for inequalities, } \\
\text { derived from factors such as: origin, ethnicity, gender, } \\
\text { language, religion, opinion, economic status, age, working } \\
\text { children, people with learning problems or special educational } \\
\text { needs in all levels and modalities of the system or of other } \\
\text { nature that affect the equality of opportunities in the exercise } \\
\text { of the right to education. Also it defines service specifications } \\
\text { for indigenous peoples. }\end{array}$ \\
\hline $\begin{array}{l}\text { Dominican } \\
\text { Republic }\end{array}$ & $\begin{array}{llr}\text { General } & \text { Law } & \text { of } \\
\text { Education } & N^{\circ} 66-97 \\
\text { (1997). } & & \end{array}$ & $\begin{array}{l}\text { Comprehensive education that allows the development of the } \\
\text { individuality and the realization of a socially usefulness } \\
\text { without any discrimination based on: race, sex, creed, } \\
\text { economic and social position or of any other nature. It seeks } \\
\text { to promote equality of learning opportunities and equality in } \\
\text { the provision of the service. }\end{array}$ \\
\hline Uruguay & $\begin{array}{l}\text { General Law of } \\
\text { Education } \mathrm{N}^{\circ} 18.437 \\
\text { (2004). }\end{array}$ & $\begin{array}{l}\text { Diversity and educational inclusion seeks to ensure the rights } \\
\text { of minority or especially vulnerable groups, in order to ensure } \\
\text { equal opportunities in the full exercise of their right to } \\
\text { education and effective social inclusion. }\end{array}$ \\
\hline Venezuela & $\begin{array}{l}\text { Organic Law } \\
\text { Education (2009). }\end{array}$ & $\begin{array}{l}\text { Democratic, participatory and protagonist education with } \\
\text { social responsibility and equality with all citizens without } \\
\text { discrimination of any kind. It defines service specifications for } \\
\text { bilingual intercultural and education in a context of the } \\
\text { countrie's limits. }\end{array}$ \\
\hline
\end{tabular}

Source. Author compilation.

\section{Understand inclusive education.ç}

Inclusive education must be understood, according to new work challenges in function of the learning needs of each student. The students' needs will not be labeled at any time by the teacher; but they will be tended with different actions. They must be given in an environment of warmth for teachers and students. Inclusive Education seeks to achieve in all students their presence, participation and academic success in all the 
different educational levels (Delgado, 2017). Table 2 categorizes the attention to diversity, allows to better guide the terminology used to make education inclusive.

Table 2.-Categorizing for attention to the diversity of students in an educational institution.

\begin{tabular}{lll}
\hline Social conditions & $\begin{array}{l}\text { Intercultural } \\
\text { conditions }\end{array}$ & Personal conditions \\
\hline Place or situation of origin & Culture & Gender identity \\
Language & Diversity & Sexual orientation \\
Risk situation & Identity & Learning problems \\
Religion and idiology & & Organic problems \\
Political afiliation & & Bullying \\
Criminal record & Conduct \\
Socio-económical situation & & Gifted students \\
Child labour & High level sportsmanship \\
& & Addictions \\
\hline
\end{tabular}

Source. Author.

\section{Model: Use of actions for an inclusive education (MAEI).}

The inclusive education described in terms of this study assesses as variables to be taken into account: social, intercultural and personal conditions that students may present. An educational model allows for a guided processes to make an inclusive education. This material shows the model that defines actions for an inclusive education, and references the work to be developed inside and outside the classrooms.

Description of the model.

The model proposed by the author describes the development of three dimensions related to: educational policies given in the field of inclusive education, the conditions presented by students, and the different actions to make an inclusive education.

Figure 1.-List of variables describing inclusive education.

\begin{tabular}{|l|}
\hline $\begin{array}{l}\text { Educational policies, proposed according to current regulations to generate an inclusive } \\
\text { work from each one of the members of the educational community. } \\
\text { Indicators, for the educational service generator team as } \\
\text { authorities, support team for inclusive education (EAEI Equipo de } \\
\text { Apoyo a la Educación Inclusiva) and teachers. }\end{array}$ \\
$\begin{array}{l}\text { Conditions of the students, social, intercultural and personal conditions are considered. } \\
\text { Indicators, for the team of teachers, the diversity of the students, will be identified } \\
\text { according to some condition that may be present. }\end{array}$ \\
\hline
\end{tabular}




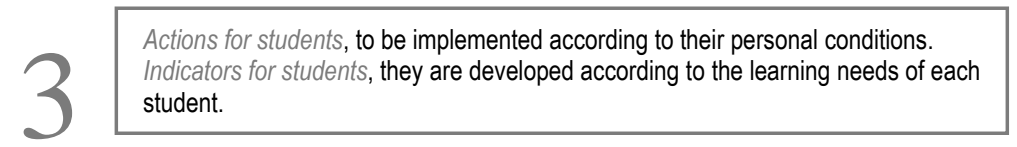

Source: Author.

Figure two shows the relationship of the variables, which will derive indicators and items. The model (MAEI) determines the value of a management effectiveness index in inclusive education, using the method of structural equations. Figure 2 graphs the relationship of the variables, being a model that can be applied at different educational levels and in any context.

Figure 2.-Use of actions for an inclusive education.

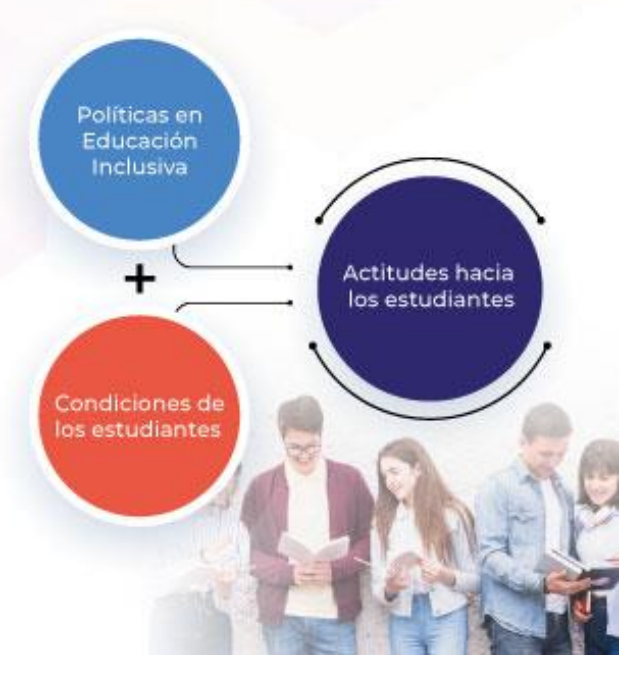

Source: Author

\section{Conclusions.}

Considering the previously described, the relevance and importance of inclusive education in the scenario of the Latin American region becomes evident. As final reflections we have:

Human rights, including the exercise of the right to education, devoted in the Universal Declaration of Human Rights, are cited in the Constitutions and the set of legal instruments given in each of the countries of the region. Education, seen as a right is the essential element to define policies, plans, programs and projects in terms 
of an educational service. They constitute a fundamental frame of reference for inclusive education aiming to be of quality and at everyone's service.

Each educational system is called to act in the definition of conditions to meet the particularities of students. This study analyzes the ways in which inclusive education, evidences the foundations framed in a focus on rights to address the diversity of students without any discrimination.

The educational policies, formed with great intentions, pass to educational actions, this may take time; but, they also define an inclusive culture in which all the actors of the educational community and citizens are responsible and work decisively to eliminate any form of discrimination.

Inclusive education goes beyond treaties, international conventions and laws, although it is true that they legitimize the rights of people with disabilities or for certain groups that are in some vulnerable condition. Inclusive education demands a change of attitude towards different people, all the members of the educational community and citizens are responsible to work decisively in favor of inclusive education of quality for all.

When approaching inclusive education, it is proposed to use the model, use of actions for inclusive education, which develops the three dimensions i) the educational policies given in the area of inclusive education, ii) the conditions affecting the students, and iii) the actions to make an inclusive education. The dimensions described present indicators as a frame of reference for the work that needs to be developed in this area.

The model with the use of actions for an inclusive education, is proposed as a reference for the work of inclusive education. It is of great importance to consider the dimensions and indicators described in order to arrive at the details of the work that needs to be developed according to the demands of each educational institution.

The development of this article is a reference for daily action in any educational institution. The EAEI is responsible for working in attention to the diversity of students by assuming work challenges to be achieved. In the end the satisfaction of a fulfilled duty as part of a process of forming of several generations that are part of a society in which we live together and free of discrimination.

\section{References.}

Argimon, J., \& Jiménez, J. (2004). Validación de cuestionarios. Madrid: Elsevier.

Benavides, G., \& Rodas, S. (2009). Protocolo de asistencia integral a personas en movilidad. Quito, Ecuador: OIM. 
Booth, T. \& Ainscow, M. (Eds). (1998). From them to us: An international study of inclusion in education. London: Routledge. 1-21.

Delgado, K. (2017). Propuesta de aplicación del enfoque de educación inclusiva en instituciones educativas pertenecientes a la Zona 9 del Distrito Metropolitano de Quito. Universidad Autónoma de Barcelona.

Delgado, K. (2019). El desafío de la educación inclusiva. Plan piloto en Ecuador. 1, 266. http://repositorio.uti.edu.ec//handle/123456789/1350

Delgado, K. (2019). La educación inclusiva en América Latina: Una cuestión de actitud. https://amzn.to/2MT700Y

Meléndez, F. (2012). Instrumento internacional sobre derechos humanos aplicables a la administración de justicia. Comparative constitutional study. 8, 21-33.

UNESCO (Ed.) (2018). Educación Superior. Sistema de Información de Tendencias Educativas en América Latina. UNESCO. https://n9.cl/wtp0

Valenciano, G. (2009). Construyendo un Concepto de Educación Inclusiva: Una experiencia compartida. Magazine Aspectos clave de la Educación Inclusiva, 13 - 24. 